\title{
Isolated Ankyloblepharon Filiforme Adnatum in a Newborn
}

\author{
Saroj Gupta* and Harsha Saxena
}

Department of Ophthalmology, All India Institute of Medical Sciences, Bhopal, India

*Corresponding author: Dr. Saroj Gupta, Additional Professor, Department of Ophthalmology, All India Institute of Medical Sciences, Saket Nagar, Bhopal, Madhya Pradesh, 462020, India, Tel: 9926550364, E-mail: sarojini94@yahoo.co.in

\begin{abstract}
We report a case of a rare congenital eyelid abnormality, ankyloblepharon filiforme adnatum, in an otherwise healthy male neonate, born to healthy parents out of non-consanguineous marriage. Newborn presented with a single band of tissue connecting left upper and lower eyelid, resulting in limited palpebral aperture opening. Antenatal history was normal. The baby was operated on the seventh day of life under local anesthesia. The eyelid band was excised at the level of each lid margin resulting in normal eye opening. No underlying ocular abnormalities were noted. Right eye examination was normal. A detail systemic examination by pediatrician failed to reveal any other congenital anomaly. Ankyloblepharon filiforme adnatum may be isolated or may present with other congenital anomalies. Therefore, the presence of eyelid bands should alert for complete systemic examination. Prompt treatment is required for proper opening of the eye and to decrease the risk of amblyopia.
\end{abstract}

\section{Keywords}

Ankyloblepharon filiforme adnatum, Congenital anomalies, Eyelid bands, Ectodermal dysplasia

\section{Introduction}

Ankyloblepharon Filiforme Adnatum (AFA) is a rare but potentially amblyopic congenital condition in which the lid margins are connected by bands of extensile tissue interfering with opening of the eyes. Von Hasner in 1982 first reported this condition [1]. Fusion of eyelids is a normal stage in fetal development, but it is abnormal at birth. The developing eyelids fuse during the $9^{\text {th }}$ week of gestation and remain fused until the fifth month, subsequently they separate but it may take up to the seventh month of gestation [2].

AFA may present as an isolated finding [3], may be associated with other congenital anomalies or it may be a part of a well-defined syndrome [4]. Therefore, it is important to look for systemic abnormalities for proper management of infant. Treatment of AFA is simple excision of tissue band from lid margins. We report a case of a newborn presenting with isolated AFA at birth, treated on the seventh day of life.

\section{Case Report}

A male baby born at 40 weeks' gestation by elective caesarean section to a 27-year-old second gravid female and 30-year-old healthy male, out of non-consanguineous marriage, was noted to have fused left eyelids at birth. The baby weighed $3100 \mathrm{gm}$. The pregnancy was normal and uneventful; no history of fever, rashes or drug intake. The previous one sibling, aged five years, male, was healthy. There was no family history of congenital anomalies. A detailed systemic assessment did not reveal any other congenital abnormality. On detail ocular examination, there was a single band of extensile tissue between left upper and lower eyelid arising from the grey line, with the limited interpalpebral aperture of $3.5 \mathrm{~mm}$ (Figure 1). The band was central in location and prevented full opening of the eyelid. Therefore, it was planned to divide the adhesion under local anesthesia. Lignocaine jelly was applied over the lid margins taking all aseptic precautions. The eyelid band was divided with Vannas scissors near each lid margin. There was minimal bleeding; no sedation or injection was required. The lids could be easily parted, the underlying eye was normal. Ocular motility, anterior segment, and fundus examination were normal. Lid edema was noted on a first postoperative day (Figure 2). At the follow-up visit, two weeks postoperatively, no abnormality was noted (Figure 3). The eyeball was opening normally. Both eyelids were normal. The examination of the right eye was also normal.

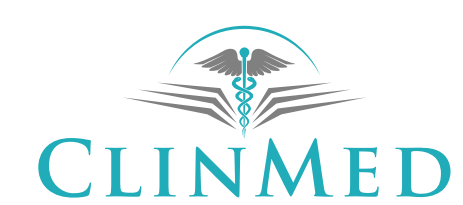

INTERNATIONAL LIBRARY
Citation: Gupta S, Saxena H (2018) Isolated Ankyloblepharon Filiforme Adnatum in a Newborn. Int J Ophthalmol Clin Res 5:086. doi.org/10.23937/2378-346X/1410086

Received: February 14, 2018: Accepted: April 24, 2018: Published: April 26, 2018

Copyright: (c) 2018 Gupta S, et al. This is an open-access article distributed under the terms of the Creative Commons Attribution License, which permits unrestricted use, distribution, and reproduction in any medium, provided the original author and source are credited. 


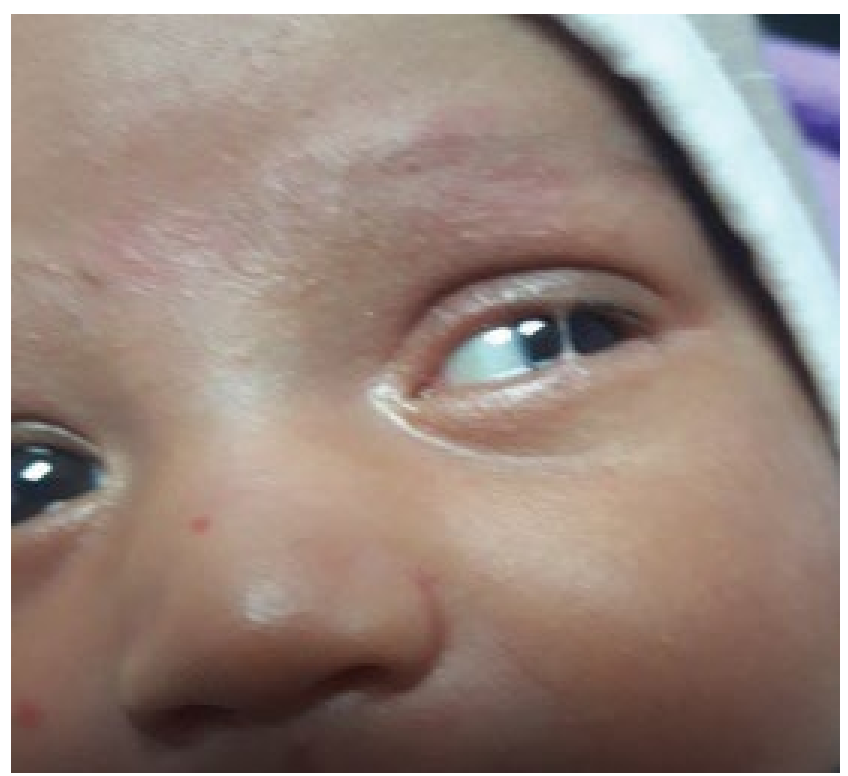

Figure 1: Photograph showing a single tissue band connecting left upper and lower eyelid margins as seen on clinical examination at birth.

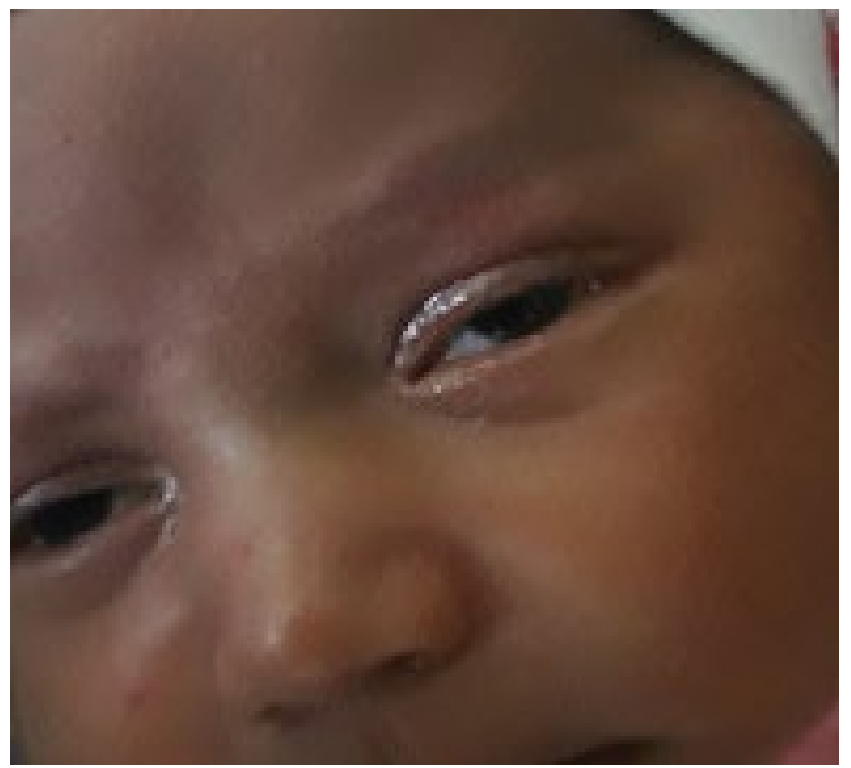

Figure 2: Lid edema on first postoperative day.

\section{Discussion}

Ankyloblepharon filiforme adnatum is characterized by bands of tissue connecting the upper and lower eyelids. Bands may be present in one or both eyes and may be single or multiple [3]. This is to be distinguished from simple ankyloblepharon wherein the lid margins are directly fused. The tissue bands are composed of a central vascular connective tissue strand surrounded by squamous epithelium. The connective tissue is usually highly cellular and embryogenic in nature [5].

AFA is usually associated with multiple malformations, suggestive of an autosomal dominant inheritance of varying degrees of penetrance. Sporadic cases have also been reported [5]. The pathogenesis of this abnormality is unknown, and a number of theories have been

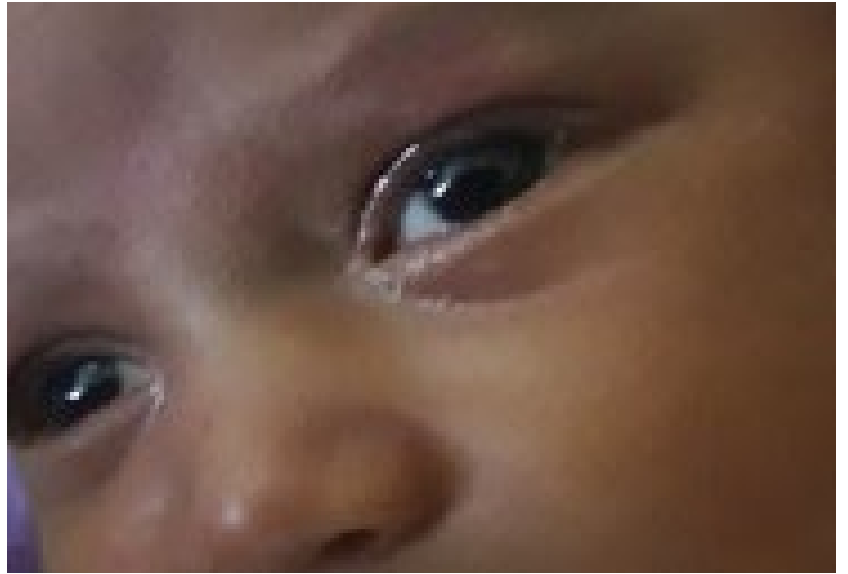

Figure 3: Completely opened eye after tissue band excision.

proposed. The most accepted theory is that of pure aberrance of development, due to a temporary arrest of the growth of epithelium and rapid proliferation of mesoderm, allowing the union of lids at abnormal positions [6]. Timely separation of the eyelids is required for proper opening of the eye and to avoid the risk of development of occlusion amblyopia, as was done in this case.

AFA may be associated with infantile glaucoma and iridogoniodysgenesis [6], trisomy 18 (Edward's syndrome), Hay-Wells syndrome (a variant of ectrodactyly-ectodermal dysplasia-cleft lip-palate syndrome) [7], or popliteal pterygium syndrome (characterized by webbing of the knees, syndactyly), curly hair, ankyloblepharon nail dysplasia syndrome (CHANDS), cardiac abnormalities such as ventricular septal defects and patent ductus arteriosus, hydrocephaly, imperforate anus and glaucoma [4].

All these rare multisystem anomalies are autosomal dominant congenital ectodermal dysplasia, linked to mutations in the TP63 gene, which plays an important role in ectodermal, craniofacial, and limb development during fetal life [8].

Rosenman, et al. divided AFA into four subgroups - Group I is not associated with any other condition whereas group II is associated with the central nervous system and cardiovascular malformation. Group III is associated with ectodermal dysplasia, group IV associated with cleft lip and cleft palate [9].

This case belongs to group one. This was the first case of AFA seen at our institute. This report demonstrates the simplicity in treating the condition and the importance of early intervention to avoid the development of amblyopia. AFA could be a sign of multisystem disease. Therefore, a thorough evaluation of other body systems, to exclude associated malformations is strongly recommended.

\section{References}

1. Von Hasner (1881) Ankyloblepharon filiforme adnatum. Z Heilkol 2: 429.

2. Sharkey D, Marlow N, Stokes J (2008) Ankyloblepharon fili- 
forme adnatum. J Pediatr 152: 594.

3. Gruener AM, Mehat MS (2009) A newborn with ankyIoblepharon filiforme adnatum: a case report. Cases $\mathrm{J} 2$ : 8146.

4. Modi AJ, Adrianwalla SD (1985) A multiple malformation syndrome with ankyloblepharon filiforme adnatum, with cleft lip and palate. Indian J Ophthalmol 33: 129-131.

5. Gupta SP, Saxena RC (1962) Ankyloblepharon filiforme adnatum. Indian J Ophthalmol 10: 19-21.

6. Scott MH, Richard JM, Farris BK (1994) Ankyloblepharon filiforme adnatum associated with infantile glaucoma and iridogoniodysgenesis. J Paediatr Ophthalmol Strabismus 31: 93-95.

7. Weiss AH, Riscile G, Kousseff BG (1992) Ankyloblepharon filiforme adnatum. Am J Med Genet 42: 369-373.

8. McGrath JA, Duijf PH, Doetsch V, Irvine AD, de Waal R, et al. (2001) Hay-Wells syndrome is caused by heterozygous missense mutations in the SAM domain of p63. Hum Mol Genet 10: 221-229.

9. Rosenman Y, Ronen S, Eidelman Al, Schimmel MS (1980) Ankyloblepharon filiforme adnatum: congenital eyelid-band syndromes. Am J Dis Child 134: 751-753. 